\title{
Conditions and factors of foreign economic cooperation in the management of the Russian economy
}

\author{
Vladimir Anatolyevich Chernov \\ Federal state Autonomous educational institution of higher education "National research \\ Lobachevsky Nizhny Novgorod state University", Nizhny Novgorod. Russia
}

\begin{abstract}
The article examines the conditions and consequences of Russia's economic cooperation with international organizations, including the IMF, WTO, EAEU, BRICS, and examines the opportunities and problems of achieving competitive advantages and investment attractiveness of Russian processing industries, and freeing Russia's dependence on fuel and raw materials exports. Discriminatory conditions and principles of equality and mutually beneficial cooperation between countries are revealed. The article highlights the means of achieving regional economic security and countering economic threats in international Finance.
\end{abstract}

\section{Introduction}

Russia's international economic cooperation is an important factor in regional economic growth, expanding sales markets, and participating in and strengthening its position in global processes. International specialization and integration of manufacturers have reached such a level in the world that most high-tech products in advanced industries are produced with the participation of several States. Economic success is also determined by the extent to which regions develop foreign markets when selling products of national production. International integration is becoming inevitable. At the same time, the most important condition for sustainable development is the preservation of the environment $[1 ; 2, \mathrm{p}$. 12196-12199].

The success of the Chinese economy lies in the colossal sources of investment on the one hand, and the most extensive geography of sales markets on the other. The Russian economy lacks both of these conditions. The development of the Russian and Chinese economies went in opposite directions in the most important aspect. China increased production of innovative high-tech products and was expanded global markets for these products, importing fuel and raw materials for production. Russia, on the contrary, expanded the production and export of fuel and raw materials, without investing in the necessary development of processing industries. As a result, the Russian economy increased its own dependence on fuel and raw materials exports, periodically experiencing deep crises due to the volatility of world prices for fuel and raw materials.

Further development of the Russian economy is impossible without the rapid development of innovative high-tech, competitive processing industries in the regions, as 
defined by decree of the President of the Russian Federation dated 07.05.2018 No. 204 "on national goals and strategic objectives of the development of the Russian Federation for the period up to 2024". The relevance of government coordination for stimulating innovation and economic growth in the regions is revealed in the article [3]. At the same time, in the specific conditions of Russia, dynamic growth of the regional economy is possible only if fuel and raw materials resources are transformed from dependence into a competitive advantage [4, p. 639-649].Let's look at how much Russia's entry into various international communities contributes to this.

\section{Experience of Russia's participation in international organizations}

Attempts by Russian regulators to expand international economic cooperation have not stopped since the collapse of the USSR. On June 1, 1992, Russia became a member of the international Monetary Fund (IMF ). The condition for cooperation with the Fund was the liberalization of Russia's domestic and foreign financial policy. Cooperation was conducted on the basis of programs that set parameters for providing financial assistance and impose obligations on the Russian state to implement specific macroeconomic policies.

One of the IMF's conditions for liberalizing foreign trade was the elimination of export duties on gas and oil with a simultaneous compensating increase in excise taxes [5]. Let's assess the consequences of this policy. Export duties on crude oil and natural gas account for a high share - about a third of the revenue received by the budget from customs payments $[6$, p. 9]. When taxing exports, these deductions are made at the expense of oil and gas companies, since the latter cannot compensate for duties by raising prices on the international market above the market price.

If export customs duties are replaced by excise taxes (according to the IMF terms), then these costs can be compensated by fuel and raw materials organizations by increasing prices on the domestic market for Russian producers and consumers, power plants running on fuel, transport organizations, etc. Cold winter conditions in most of the Russian regions require high fuel and electricity costs for heating. As a result, the costs of production, electricity, and transport services are growing, which means that the profitability, competitiveness, and opportunities for investment in innovative development of manufacturers, which are already experiencing an acute lack of funding, are decreasing. As a result, the investment attractiveness of Russian production is reduced, and investment is extremely insufficient. It is known that due to long distances in Russia, transport costs take up a significant share in the cost of production, which significantly affects the price component of manufactured products [7]. As a result of their increase, prices for most other goods are rising, inflation is increasing, and the ruble is losing its position relative to foreign currencies.

In result, the fuel and raw materials sector of industry reaches a higher level of profitability through the rest of the economy that we are seeing in table. 1 . The higher the profitability of the fuel and raw materials sector of the economy allows them to significantly increase spending on the wages of employees relative to the processing industries (table. 2) and pay high dividends, which processing industries lack. Such interdependencies are disclosed in the article [8]. 
Table 1. Profitability of products (goods, works, services) by type of economic activity (in percent) $[9$, p. 356]

\begin{tabular}{|l|c|c|}
\hline \multicolumn{1}{|c|}{ Profitability by type of economic activity } & \multicolumn{2}{|c|}{ Years } \\
\cline { 2 - 3 } & 2017 & 2018 \\
\hline Miningofthetotal & 24,6 & 31,4 \\
\hline Fromthem: & 24,1 & 32,9 \\
\hline - crude oil and natural gas production & 47,4 & 55,9 \\
\hline - miningofmetalores. & 10,9 & 12 \\
\hline Manufacturingindustriestotal & & \\
\hline Fromthem: & 7,7 & 7,8 \\
\hline - foodproduction & 7,7 & 8,3 \\
\hline - clothingproduction & 25 & 21,6 \\
\hline - production of medicines and materials used for medical & 15 & 12 \\
\hline - manufacture of computers, electronic and optical products & 7,6 & 3,2 \\
\hline - production of machinery and equipment & 2,6 & 2,3 \\
\hline - production of motor vehicles, trailers and semi-trailers & 5,3 & 4,9 \\
\hline - furnitureproduction & 16 & 17,8 \\
\hline Fgriculture, forestry, hunting, fishing and fish farming & 43,8 & 44,7 \\
\hline
\end{tabular}

Reverse situation: an increase in export customs duties not only significantly replenishes the state budget, but also increases the country's financial benefits from the sale of fuel and raw materials on the domestic market, which encourages an increase in the supply of fuel and raw materials on the domestic market, contributing to lower prices for fuel and raw materials. This is the way to reduce production costs, increase profitability and competitiveness, increase investment opportunities in innovative development, reduce prices for Russian manufacturers ' goods, increase the investment attractiveness of Russian businesses, reduce inflation, and strengthen the ruble on the world market.

Table 2. Average monthly nominal accrued salary of employees of organizations (RUB) [9, p. 156]

\begin{tabular}{|c|c|c|c|c|}
\hline \multirow{2}{*}{ Wages by type of economic activity } & \multicolumn{4}{|c|}{ Years } \\
\hline & 2010 & 2016 & 2017 & 2018 \\
\hline Miningofthetotal & 39898 & 69942 & 74474 & 83178 \\
\hline \multicolumn{5}{|l|}{ Fromthem: } \\
\hline - crude oil and natural gas production & 60691 & 100853 & 104078 & 127771 \\
\hline - miningofmetalores. & 3226 & 60726 & 61122 & 70721 \\
\hline Manufacturingindustriestotal & 18991 & 34562 & 38502 & 40722 \\
\hline \multicolumn{5}{|l|}{ Fromthem: } \\
\hline - foodproduction & 16103 & 27665 & 29920 & 32272 \\
\hline - clothingproduction & 9801 & 15453 & 20299 & 19819 \\
\hline $\begin{array}{l}\text { - manufacture of computers, electronic and optical } \\
\text { products }\end{array}$ & 20303 & 43737 & 46928 & 51492 \\
\hline - production of machinery and equipment & 18941 & 33556 & 37472 & 40036 \\
\hline $\begin{array}{l}\text { - production of motor vehicles, trailers and semi- } \\
\text { trailers }\end{array}$ & 17818 & 34446 & 38133 & 42015 \\
\hline - furnitureproduction & 12367 & 19517 & 22188 & 24213 \\
\hline Agriculture, forestry, hunting, fishing and fish farming & 11109 & 22915 & 25671 & 28699 \\
\hline
\end{tabular}

Thus, in order to reduce the dependence of the budget system's revenues on the oil and gas sector and turn natural resources into competitive advantages, it is necessary to stop hidden subsidies to the fuel and raw materials industries through tax incentives, refuse 
export duties, and refund "incoming" VAT on the export of hydrocarbons as measures of economic restructuring.

As we can see, the IMF conditions deprive the Russian economy of such opportunities by banning export duties on fuel and raw materials. As you know, Russia has fully repaid its obligations to the IMF on existing debt, freeing itself from discriminatory obligations to the IMF.

Participation in the world Trade Organization (WTO) since August 22, 2012 has had no less impact on the Russian economy. According to the Ministry of economic development of the Russian Federation [10], Russia sets the following goals for such participation:

- Establish Russia as a reliable strategic partner in international trade relations, improving the country's image.

- Partnership in the development of rules so that their drafting takes into account the national interests of the Russian Federation.

- Creating more favorable conditions for entering the international market, stabilizing trade relations with achieving predictability and transparency in foreign economic policy with WTO members.

- Access to WTO mechanisms to eliminate discrimination in trade, resolve disputes, and protect national interests from infringement.

- Improvement of conditions for foreign investment based on changes in legislation under WTO rules.

- Getting new opportunities for Russian investments abroad.

- Increasing the competitiveness of Russian production in the Russian market in open competition with the increased flow of foreign goods and investments.

Did Russia's accession to the WTO contribute to achieving such a goal as Creating more favorable conditions for entering the international market and stabilizing trade relations with achieving predictability and transparency in foreign economic policy with WTO members? The aggravation of international relations after the crisis in Ukraine has led to increased pressure on Russia, which is not consistent with the terms of cooperation of the WTO countries.

The next goal: Access to WTO mechanisms to eliminate discrimination in trade, resolve disputes, and protect national interests from infringement. This goal has become unattainable in the context of sanctions confrontations.

And the most important goal is to Improve the conditions for foreign investment by changing the legislation in accordance with the WTO rules. To achieve this goal, it is necessary to increase the investment attractiveness of the Russian economy. This requires that Russian manufacturers have competitive advantages. The main competitive advantage of production in Russia, as it was noted, can be the existing abundance of natural fuel and raw materials. However, Russia's natural resources still remain a fuel and raw material dependency of the Russian economy, rather than a competitive advantage.

According to the documents on Russia's accession to the WTO, export duties for hydrocarbons (crude oil and gas condensate) depend on the world price of crude oil. So, if this price is set at a level below or equal to 109.5 us dollars per ton, the export duty is not applied. Since August 2008, the world price of oil has fallen below this value, and now it has fallen to 48.99 US dollars per barrel of Brent [11]. Consequently, the WTO terms remain no less discriminatory for Russia than the IMF terms, which deprive the Russian economy of its main competitive advantage.

With the transition under the WTO terms to the principle of equal to the yield in pricing natural gas supplies to domestic and foreign markets, the costs of petrochemical enterprises for electricity and fuel gas have increased. This further weakened the position of the chemical and petrochemical industries in the production of plastics, paint coatings, and 
rubber products. At the same time, small businesses suffered the most. Such consequences were the result of the liberalization of foreign trade when Russia joined the WTO [6. c. 30].

In 2014-2015, the Eurasian Economic Union (EAEU) was established on the territory of the former Soviet Union to unite efforts and cooperate more closely in ensuring economic security, as well as to jointly confront global economic threats. It replaced the Eurasian Economic Community(EurAsEC) that existed in 2001-2014.

In June 2006, the international organization BRICS was established within the framework of the St. Petersburg economic forum (PEF) with the participation of the Ministers of economy of Brazil, Russia, India, and China.

The systematic tightening of sanctions by the United States and the aggravation of political relations force the authorities of Russia and other countries to reinsure themselves and get rid of American assets, including the dollar [12]. The growing us debt calls into question whether the dollar quotes correspond to an adequate assessment. Some researchers propose new classifications of exchange rate regimes in the form of centre of a space of alternative classifications [13].

The countries of the EAEU and BRICS have consistently are exempted from dollar pressure by using national currencies in international settlements. They replace dollars with gold and yuan in gold and foreign exchange reserves, are released from us debt securities by consistently reducing the share of US government debt in government reserves. [12].

The new international development Bank BRICS, established in 2014-2015 and its interaction with development banks with the participation of BRICS, contributes to constructive financial cooperation between the countries. This cooperation is achieved by the pooling of resources for co-financing of projects and development programmes. These banks function as financial intermediaries, providing indirect financing. They are also participants in the BRICS stock markets, where they perform the function of direct financing of projects and development programs [14, p. 120]. The volume of project financing by BRICS development banks in the currencies of the member States has been increasing in recent years. For the period from 2016 to 2018, the total amount of financing by the new development Bank in national currencies amounted to 6.2 billion rubles. yuan[15, c. 115].

\section{Conclusion}

And so, we are seeing a trend towards the formation of new international organizations that strive for equal and mutually beneficial cooperation. The BRICS member countries signed the Johannesburg Declaration, committing themselves to expand strategic partnership, improving the well-being of citizens, and ensuring a fairer strand of international interaction [14, p. 113]. This is facilitated by the creation of a fair (non-discriminatory) legal system [15, p. 118]. The new development Bank BRICS is committed to the principles of equality and mutually beneficial cooperation. These principles will contribute to its leading position in supporting the development of countries that interact with BRICS $[15$, p. 114].

Thus, the most important condition for the financial sovereignty of Russian Finance and achieving sustainable innovative high-tech development is a careful choice of the nature and conditions of interaction with international market entities on the principles of equal and mutually beneficial cooperation with a thorough analysis of their economic consequences based on the fundamental laws of the market disclosed in the source $[16, \mathrm{p}$. 124-133], and not speculative approaches. 


\section{References}

1. V.A. Chernov, 36th IBIMA Conference: 4-5 Water Resources and Achieving a Comprehensive Balance of the three Compo-nents of Sustainable Development. Granada, Spain (2020.)

2. A.V. Agibalov, L.A. Zaporozhtseva, V. Malitskaya, M.B. Chirkova, N.Gorlova, International Journal of Recent Technology and Engineering, 8(4), 12196 (2019)

3. J. Perilla, The Journal of International Trade \& Economic Development, 29. 1-26 (2020)

4. V. T. Riazanov, St Petersburg University Journal of Economic Studies, 34(4), 639 (2018)

5. RIA of news. When and under what conditions Russia received loans from the IMF. 24.02.2014, https://expert.ru/

6. S. F. Sutyrin et al. Saint Petersburg-Geneva: Saint Petersburg state University. International trade center. Russia's accession to the WTO: main obligations, possible consequences (2012), https://www.intracen.org/

7. V.A. Chernov, VIII International Scientific Conference Transport of Siberia Managing the performance of transport organizations. Article number 012036.: IOP Conference Series: Materials Science and Engineering 918 012036. (2020).

8. T. D. Lam. The Journal of International Trade \& Economic Development. Effect of international trade on wage inequality with endogenous technology choice, 1 (2020).

9. Russian Statistical Yearbook 2019: Stat .book(2019)

10. Ministry of economic development of the Russian Federation.Russia's participation in the WTO. Priority direction, https://www.economy.gov.ru

11. Ministry of Finance. The price of oil today, https://index.minfin.com.ua/

12. G. Nikolaev, Business newspaper "Vzglyad". Rambler/Finance. Russia says goodbye to American debts18.09.2019 (In Russ.), https://finance.rambler.ru/

13. M.Dąbrowski, M.Papież, S.Śmiech, The Journal of International Trade \& Economic Development,1 (2020).

14. I.Z.Yarygina, A.V. Zhiglyaeva, Ekonomika. Nalogi. Pravo = Economics, taxes \& law, 13(4), 110 (2020)

15. I.Z.Yarygina, O.A. Borovikova, Ekonomika. Nalogi. Pravo $=$ Economics, taxes $\&$ law,12(4), 111 (2019)

16. Chernov V.A. Finansy: teoriya i praktika = Finance. Theory and Practice, 22(2), 124 (2018) 